\title{
Food Consumption Pattern in Eskisehir
}

\author{
Amir Azam ${ }^{1} \&$ Hakan Acaroğlu ${ }^{2}$ \\ ${ }^{1}$ Abdul Wali Khan University Mardan, Bacha Khan Campus Seen Lasht Chitral, Pakistan \\ ${ }^{2}$ Eskisehir Osmangazi University, Faculty of Economics and Administrative Sciences, Department of Economics, \\ Eskisehir, Turkey \\ Correspondence: Hakan Acaroğlu, Assistant Professor, Eskisehir Osmangazi University, Faculty of Economics and \\ Administrative Sciences, Department of Economics, 26480, Eskisehir, Turkey. Tel: 90-222-239-3750/1750.
}

Received: November 24, 2015

doi:10.5430/ijfr.v7n1p101
Accepted: December 14, 2015

Online Published: December 28, 2015

URL: http://dx.doi.org/10.5430/ijfr.v7n1p101

\begin{abstract}
The aim of the study is to find out the behavior of the resident of Eskisehir, about the relationship between the expenditure that are made by them on different food commodities by taking income of the household and the family size of the respondent as important explanatory variable by using the econometric method of Ordinary Least Squares (OLS). A sample size of 100 households is studied on the study area in Eskisehir. The average household size in the study area is recorded 4 members/ family. The household size is ranged from 1-11 members. Average household monthly income is 616 Turkish Liras (TL)/weak. The average percentage of income spend on food is $42.39 \%$ of total income. Income of the household and size of the household are positively correlated with the consumption of various food items.
\end{abstract}

Keywords: food consumption pattern, weekly income, weekly expenditure, household size

\section{Introduction}

Economics being social science gives much more emphasis on the major aspects of social life that is mainly related towards the maintenance of life and improvement of its conditions. Regarding the main focus on the basic aspects of social life different activities are being practiced whose sole purpose is to encompass consumption, whose pattern and composition determines the standard of living at micro as well as macro level.

Among the consumption, food consumption is of the utmost importance, because food is the basic need of human existence. It is the food, which can build up the link between body and soul. Food is one of the basic necessities of human life without which no human life existence is possible. For a quality living, sound human health occupies the main position. But unfortunately, there is a great level of ignorance and lack of awareness among the masses about the balance diet, which can come out in the form of different health problems. Food consumption pattern is a dynamic process. It can be defined in terms of consumer behavior formed by the consumer's tastes and preferences. The main factor determining the food consumption pattern is income. However, certain other factors such as size and composition of household, distribution of income, level and distribution of assets, number of earning hands in a family, people's preferences, likes and dislikes, prices of food items, geographical and climatic differences etc. influence the food consumption pattern (Gumus et al., 2010).

With the advancement in general and health education in specific, people get awareness and try to shift from imbalance diet package to balanced diet. For the purpose of food security, sound health and delineation of sound food policies, the knowledge concerning the changing food consumption is very crucial. Food dynamics are important aspects of life. Consumption patterns are changing over time. The level and distribution of food consumption is a vital indicator of social welfare (Regimi et al.). Although there is a list of determinants which can bring change in food consumption pattern, income is one of the players in the determination of consumption of the quantities of different food items. Generally the consumer with low income make large share of expenditure in the consumption of different food items. The upper class and median class mostly expend their income on personal services and other non-food items.

The city of Eskisehir is situated in $233 \mathrm{~km}$ away from Ankara in West and $330 \mathrm{~km}$ away from Istanbul in southeast. Eskisehir is known as the university town because two of the two universities; Eskisehir Osmangazi University and Anadolu University are situated in this province. According to (TurkStat, 2014), the total population of Eskisehir is 824,124 . The province has been divided into 14 districts. Eskisehir's population has a high literacy level for Turkey at 
about $99 \%$ of the population. The average size of the family in Eskisehir is four family members. The average income of the family is about $2660 \mathrm{TL}$. The average expenditure on food item in the study area is $37 \%$ of the total income while in "the country it is $20 \%$ and mostly on normal goods" (Bozoglu et.al., 2013).

The purpose of study is to find out how the income level and the household size affect the food consumption patterns in Eskisehir. We want to find out what are the consumer preferences at certain level of income and its relationship with household size.

Generally, the main focus of the study is to analyze the food consumption expenditure and their determinants. However, our research has the following specific objectives.

- To determine the household's food consumption patterns in Eskisehir.

- To estimate the household in total as well as relative expenditure on food items and the proportion of total income spent on food in Eskisehir.

The following hypotheses will be tested through this study. It was assumed that:

- The higher the income level, higher will be the consumption level.

- The larger the household's size, the larger will be the consumption level.

Many studies regarding the relationship between income and food expenditure has done in different areas Turkey. However, no such attempt has made so far in case of study area. The present research underscores the factors affecting the changes in the consumption patterns in the study area. The consumption on food and their determinants were the focus of the study.

The paper consists of six sections. The second section presents the literature of the previous studies conducted by different economists in different areas related to the topic. In third section we will make our focus on the data sources and material and method used to perform the study. In section four we will check out the analytical techniques which we use to prove our hypothesis. In this section we will analyze the data through computer software and we will present the result. Additionally this section circulates around the correlation between different variable which we have used to keep up our study. In final section we will draw a short conclusion and policy recommendation about our study, and we will give some suggestion for new researchers.

\section{Literature Review}

Salama (1995), reported that the consumption patterns of food groups in Egypt were formulated and expenditure patterns in the context of Egyptian economic policy were examined. Results indicated that food budget share, propensities to consume and expenditure elasticity's were higher in rural than in urban areas. The expenditure elasticity's of demand for all food groups apart from fruit, fish and milk were less than one and statistically significant. Demand for food in Egypt was still not being met by supply. The rate of increase in food consumption was dependent on household size and population growth. Socioeconomic and national population programs should be implemented simultaneously.

Praduman \& Mathur (1996), examined the changes in food consumption patterns in India and decomposes the changes into price, income and non-price (structural shift) effects. The study indicated that the structural changes in food demand overtime within rurallurban areas appear to be substantial. In addition, to structural change, price effect on food demand was substantially higher than the income effects. Structural shifts account for most of the decrease in food grains (except wheat) consumption over time. In case of rice, the price effect was offset by non-price factors. Positive structural shift was estimated for the consumption of milk, fruits and vegetables, both among the rural and urban population.

Grimard (1996), conducted a survey study to find out the relationship among the income and food consumption on calorie taking base in some developing countries. In his study, he found that the relationship among the calories consumption food and the changes in income are interrelated. By taking Pakistan as his case study, Grimard focused on both rural and urban areas and studied the behavior of their consumption pattern. He used a household data set from Pakistan the household income and expenditure survey, for the period July1984-June 1985, including 9119 rural households and 7461 urban households and estimated calories income elasticity's for rural and urban household. He found that the elasticity was significantly different from zero. The outcomes of the studies differ from among household according their incomes. The responsiveness of lower income families in taking food calories changes more sharply as compare to other household families. So from the study of Grimard it becomes clear that the changes in income also change the food consumption pattern. 
Murad (1998), conducted a study related to 200 households. The analysis of the fruit consumption expenditure carried out for the two types of household ended up with the following conclusions: (a) whereas the consumption of malta, kino, banana, apple and guava and the income and size of household appeared to be the major determinants of fruits consumption expenditure in urban area, the consumption of kino and household income found significant in affecting the fruits consumption expenditure in rural area. (b) the household's size showed significant contribution in determining total fruits consumption expenditure in both urban and rural areas. (c) The level of income worked only in urban household cases did not work differently for both urban and rural household. (d) Whereas the elasticities of fruit consumption expenditure with respect to its various determinants were found in inelastic range for both urban and rural areas, the elasticities for urban households were higher relative to that of rural households. Meenakshi et al. (1997), analyzed India's food expenditure pattern over the period 1972-73 and 1987-88 taking account of regional differences in consumer preferences and consumer prices. The analysis used state level data, which was estimated separately for rural and urban areas. Using a complete demand systems framework, the paper used demographic information on the number of adults and children in the household, along with economic variables, namely prices and aggregate expenditure, to explain the observed differences in household expenditure on principal food items. Household composition was found to be an important determinant of consumption, although the nature of demographic impact varied across regions.

Popkin (2001) states that, examinations of purchasing power of peoples best understand by finding the relationship between level of education or income, their consumption at different amounts or types were also revealing. Research conducted in China shows that there is clear shift in purchasing power in relation to income level over the past decade. The analysis shows that how increase in income in China affects the poor verses the rich in different manner.

Seale et al., (2003), examined the low income countries that they spent greater portion of their income on basic necessities such as food, while richer countries spent greater portion of their income on luxuries. He found that low income countries are more responsive to changes in income and food prices so as larger adjustment in the food consumptions patterns when income and price change. The paper also finds that the changes in the earnings of the different groups in a country is mostly adjustment occurs in case of low earning class and middle earners. They make positive adjustment in their food demand.

The brief literature review highlights that income plays a major role in determination of the type and quantity of food commodities consumption. It also shows that household composition is found to be an important determinant of consumption, although the nature of demographic impact varied across regions. Low-income people spent more portions of their total household income on food commodities relative to high-income people (Garcia \& Albisu, 2001). It also shows that when there is increase in income it causes change in food consumption patterns of both low and high-income people.

\section{Materials and Methods}

A sample size of 100 households is selected through systematic random sampling for the data collection purpose. To represent the whole population we divide the whole area into such a way that could represent the population as a whole. We take three different parts of Eskisehir such that they are denoting the whole population from High developed to low developed. We conduct our study on Atatürk Bulvarı, Osmangazi and one of the remote area means away from the city center. We distribute the whole sample area into 33 household samples from each area randomly.

\section{Analytical Techniques}

The analysis depends on primary data. Averages of actual quantities of every food item consumed will calculate to find out the average consumption of food items as an average household in the research. The following econometric model was used in this research.

$$
\mathrm{Ci}=\mathrm{f}(\mathrm{Pi}+\mathrm{TI}+\mathrm{HS})
$$

Where $\mathrm{i}=1 \ldots \mathrm{n}, \mathrm{Ci}=$ quantity consumed of ith commodity, $\mathrm{Pi}=$ price of $i$ th food commodity, $\mathrm{TI}=$ total income of household, and $\mathrm{HS}=$ household size.

Percentage expenditure of each selected food item will calculate for finding out the percentage share of food items in total expenditure and in total household income. Equation 1 will further specify and estimate in the following model. This model will use to estimate the contribution of different factors affecting the expenditure on specified food items.

$$
\text { Expenditure on Fdi }=\mathrm{B} 0+\mathrm{Bi} \mathrm{TI}+\mathrm{B} 2 \mathrm{HS}+\mathrm{U}
$$

Where Exp. on Fdi = Expenditure on ith food commodity, $\mathrm{B}=$ regression coefficient, $\mathrm{U}=$ error term.

Expenditure on Food Commodities in Sample Area: 
This section summarizes the expenditure on various food commodities as percent of total expenditure on all food items as well as percent of total household income. In addition to that, the monthly expenditure of an average household incurred on various food commodities was calculated. Considering all these purposes it is looked for descriptive statistics in below.

Table 1. Descriptive statistics

\begin{tabular}{llll}
\hline & WEEKLYINCOME* & HH** & EXPENDITURE*** \\
\hline Mean & 616.3300 & 4.290000 & 42.39000 \\
Median & 544.5000 & 4.000000 & 40.00000 \\
Maximum & 2178.000 & 11.00000 & 80.00000 \\
Minimum & 133.0000 & 1.000000 & 15.00000 \\
Std. Dev. & 420.9942 & 1.343108 & 14.55321 \\
Probability & 0.000000 & 0.000000 & 0.009191 \\
SumSq. Dev. & 17546372 & 178.5900 & 20967.79 \\
\hline Observations & 100 & 100 & 100 \\
\hline
\end{tabular}

Note: * Weekly Income Recorded in the study Area, ${ }^{* *} \mathrm{HH}$, house hold size, $* * * \%$ weekly expenditure made by the respondent in the study area.

Table 1 indicates some basic information about the study area. According to the result the average weekly income in the study area was recorded as 616 Turkish Liras with a maximum of 2178 Turkish Liras and minimum 133 Turkish Liras. Average family size in the study area is recorded as there are 4.28 family members are living in a family where the maximum frequency was recorded as 11 while minimum was 1 . This show that normally in a family the parents are living with their two children. The behavior of the people in the expenditure on food commodities is also differs from family to family or respondent to respondent. The average weekly family expenditure in the study area is about $42 \%$ of total income. Median expenditure in the study is recorded as $40 \%$ of the total income with $15 \%$ as minimum and $80 \%$ as maximum expenditure. The standard deviation about expenditure on food item is also slightly lower shows that families' expenditure is deviating from each other as $15 \%$.

Consumption of Food Commodities:

The major food items used in the research can be broadly classified into the following groups.

a. Flour: Mostly wheat flour.

b. Ghee/ cooking oil

c. Tea: Sugar, Milk, Black Tea, Green Tea

d. Pulses: Almost all kinds of pulses

e. Vegetables: All kinds of Seasonal vegetables

f. Rice. Almost all kinds of rice

g. Fruits: All kinds of seasonal fruits

The statistical analysis of the consumption of each group (food item) is illustrated in the following section.

Table 2. OLS analysis between expenditure and consumption

\begin{tabular}{lllll}
\hline Variable & Coefficient & Std. Error & t-Statistic & Prob. \\
\hline C & 28.09216 & 4.610330 & 6.093307 & $0.0000^{* *}$ \\
HH & 0.275598 & 1.067233 & 3.258236 & 0.0068 \\
WINCOME & 0.021613 & 0.003290 & 6.568828 & $0.0000^{* *}$ \\
FLOUR & 0.216246 & 0.236311 & 1.915090 & 0.0026
\end{tabular}




\begin{tabular}{lllll} 
OIL & 0.001097 & 0.239181 & 2.004585 & 0.0064 \\
CHEEZE & 0.054266 & 0.107905 & 4.502902 & $0.0003^{*}$ \\
SUGAR & 0.117346 & 0.301702 & 3.388948 & $0.0002^{*}$ \\
BTEA & 0.108049 & 0.147484 & 2.732616 & $0.0057^{*}$ \\
GTEA & 0.127130 & 0.183935 & 0.691169 & $0.0012^{*}$ \\
PULSES & 0.063708 & 0.132426 & 1.481085 & 0.0216 \\
\hline R-sq. & 0.402853 & Mean dependent var. & 42.39000 \\
Adjusted R-sq. & 0.343139 & S.D. dependent var. & 14.55321 \\
S.E. of reg. & 11.79494 & Sum squared resid. & 12520.85 \\
Prob (F-stat.) & 0.000000 & F-stat. & 6.746304 \\
\hline
\end{tabular}

Note: Dependent variable: EXPENDITURE, Method: Least Squares, Sample: 100, Included observations: 100, and * denotes; $\% 10$ significance level, ** denotes; $\% 5$ significance level.

The Table 2 suggests that how the dependent variable are influenced by the explanatory variables. By the term expenditure as dependent variable means that how much the proportion of income is expended on different food commodities as percentage of the income group. The coefficient of OLS model " $\mathrm{C}$ " indicates that explanatory variables are affecting the dependent variable as $28.09 \%$. The value of other coefficient are also indicates that how much they are affecting the dependent variable.

\section{Expenditure and Household size (HH):}

The total population of the Eskisehir is 842 thousands, out of which a total sample size of 100 household were taken to represents the population as a whole. The average family size or household size in the study area is recorded as 4 members are living in a house. The average number of house hold size in the study area indicates that increase per household size leads to increase $27.55 \%$ in consumption of different food items. This shows that the variable is positively correlated with the dependent variable. The value of coefficient of Household size or house hold member is significant because the value of " $t$ " statistics is greater than 2 at $5 \%$ level of significant.

\section{Expenditure and Income:}

Income plays a key role in the determination of most part of economic and social activities. In our hypothesis we have mentioned that income is positively related to consumption of food items ( $\mathrm{d} \&$ Shapiro, 1976). In the Table 2 it shows that the value of coefficient of Income is positively related to that of consumption expenditure. The rise in income leads to change $0.021 \%$ change in the consumption of different commodities. The average income in the study area is recorded as 2660 Turkish Lira Per month. The average household spends the $42 \%$ of their income on different commodities. The value of "t" statistics is also significant. Both the value of R2 and Durbin Watson statistics indicates that the change in income is positively drive up the expenditure of the household in different commodities in positive way. The increase in income $1 \$$ leads to increase 21 cents in the consumption of different commodities.

\section{Expenditure and Consumption of Flour:}

Flour is one of the basic variable uses in different commodities. The average family members in the study areas consume $2 \mathrm{~kg}$ of flour weekly. The calculation indicates that it is has also a significant value at $5 \%$ significant level whose value is greater than 2 and the coefficient is also engaged a positive connection with expenditure.

\section{Expenditure and Oil:}

Mostly the consumption of Oil is made up in the study area is significant response showing that the population made an average expenditure of 8.5 Turkish liras on the consumption of oil. The family members made average expenditure mostly on the olive oil and on general oil.

Consumption of Cheese in Eskisehir:

Cheese is considered as one of the major food item used in Breakfast. In Eskisehir the behavior of the people on the consumption of cheese is significantly positive. The people used cheese as one of the major item in their breakfast. On average, the respondents showed that they are consuming one $\mathrm{kg}$ in house, and they are making an expenditure of 
Turkish Liras 16 on the consumption of cheese. In the perspective of consumption of different food commodities, Cheese is also one of the major components of food expenditure. The above Table suggests that increase in total food expenditure is also due to increase in the consumption of cheese and the " $\mathrm{t}$ " statistics also suggests that it is also significant and positive shows that higher the income increase the consumption of cheese and large family size also grew up the consumption of cheese.

Expenditure and Consumption of Sugar:

The overall calculation gives us the result that both high income and large family size also rise the consumption of sugar. On average the citizens consume $2 \mathrm{~kg}$ of sugar and made an expenditure of 7 Turkish Liras on the consumption of sugar.

Usage of Turkish Tea:

Turkish Black Tea is considered as one of the great recognition of Turkish People. It is use as one of the important part of the citizens they are using Turkish Tea as major component of their refresher. Usually tea is considered and takes as the major component of Breakfast in developing countries, but in Turkey the people use black tea as more importantly and anytime. The consumption of black tea is very good for health, so the people consume an average of $1 \mathrm{~kg}$ in each family and it corresponds to nearly 13 Turkish Liras. The result suggests that the behavior of the consumption of black tea raises with raises the size of the family and slightly change occur when the income rises.

\section{Consumption of Pulses:}

As it is stated in Ofuya \& Akhidue (2005), "Pulse when eaten with cereals, can also help to increase the protein quality of the meal. In man, protein helps in the repair of body tissue, synthesis of enzymes and hormones and also in the supply of energy. In children, the consumption of pulses should be encouraged, particularly where animal protein is scarce and expensive, as this would help to furnish the child with the necessary amino acids required for growth." (Note 1) "Turkey is also the main pulse producer in the Middle East and one of the leading producers in the world. The pulse output increased from 617,000 tons in the early 1970s to 1.1 million tons in the 1980s and 1.6 million tons in 1998. Since the mid-1990s, over 60 countries import Turkish pulses, primarily chickpeas and lentils" (Note 2). In the study area it has been pointed out that on average the household consume $2 \mathrm{~kg}$ of different types of pulses by making an average of 13 Turkish Liras.

Vegetables and the study area:

The usage of Fruit and Vegetables is considered as one of the important part human balance diet. By eating fruits and vegetables, the risk of many chronic diseases can be decrease. Vegetables gives us many and important sources of nutrients including potassium, fiber, folate and different vitamins. Eskisehir is also famous for its production of vegetables and fruits. The residents of the city usually like tomatoes, potatoes, onions, chilies etc. On average the respondents says they are consuming about $7 \mathrm{~kg}$ of different vegetables as tomatoes and potatoes are top on their preferences. They are making an expenditure of 30 Turkish liras on the consumption of vegetables. It denotes that the resident of the study area are making focus on balance diet. Because in the small family size like four family members the consumption of around $7 \mathrm{~kg}$ of different vegetables shows that the respondent give equal importance to balance diet.

Expenditure and Fruits:

Fruits are also considered as important part of balance diet (Kennedy \& Claude, 2011). There is well known phrase that "keep an apple per day keeps doctor away". Importance of fruits in human diet is well recognized. Man cannot live on cereals. Fruit and vegetables are essential for balance diet and good health (Chern, et al., 2002). "Nutrionist advocate 60- $85 \mathrm{gm}$ of fruits and $360 \mathrm{~g}$ vegetable per capita per day in addition to cereals, pulse, egg etc. Fruits are good source of vitamins and minerals without which human body cannot maintain proper health and develop resistance to disease. They also contain pectin, cellulose that stimulates intestinal activities and energy giving substances like oils, fats, and proteins" (Note 3). In Eskisehir, the people are using apple, orange, pomegranate as their major source fruits. The household usually consume about $5 \mathrm{~kg}$ fruits weekly and the trend is comparatively rising with increase in income.

\section{Expenditure on Meat, Fish and Poultry:}

One of the important parts of human consumption is the consumption of protein fat items. Those are very important for the growth of human being and growth of mental ability. In the study area, it is recorded that the respondent are making the consumption of Meat, Fish and Poultry as one of the most important part of their daily consumption. On average, they are making an expenditure of 61 Turkish Liras and this expenditure varies from different level of 
income groups. The people who have low income are making very least expenses on the consumption of these groups, but those who have good income source are making good expenditure on the consumption of these food items. The average expenditure showed by the respondent is that they are consuming an average of Meat, Fish and Poultry with the amount of $31.575,13.5$ and 16.475 respectively.

Table 3. Correlation between different variables with expenditure

\begin{tabular}{lllllllll}
\hline & Exp. & HH & Income & Flour & Oil & Cheeze & Sugar & Btea \\
Exp. & 1.0000 & 0.23962 & 0.616518 & 0.152462 & 0.025868 & 0.254961 & 0.187096 & 0.183192
\end{tabular}

Note: Expenditure variable is abbreviated as "Exp." in first column and row.

The Table 3 indicates that how the variables are response to the dependent variable in the mode i.e. Expenditure. This shows that all the variables are positively related to the expenditure. There are $23 \%$ chances occur that increase in house hold size leads to increase in the consumption of different commodities. Means higher will be the household size higher will be expenditure on food commodities. Income plays a fundamental key role in most economic and social activities. The calculation indicates that $61 \%$ chances are this that increases in the income of the household leads also to increase in the expenditure of different commodities. The consumption of flour is also get positive response that if there is an increase in the consumption of food items then consumption of flour is also rises. Mostly the people in the study area are taking two meals a day like breakfast and dinner, while the lunch time took place in official or school timing so mostly the people takes the lunch out from the home. The consumption of oil, cheese, sugar, and black tea all variables are showing positive relation with that of expenditure. Hence, we can say that mostly rise in income and household size leads to increase the expenditure on food items.

\section{Conclusion}

The study suggests that how the dependent variable is explained by different component related to expenditure. The dependent variable is explained by almost $42 \%$ by the different explanatory variables. Income and the household size are considered as the main determinant of expenditure in the study and this study suggests that increase in the level of income will also lead to increase in the expenditure is made by the household on the consumption of different food items. Larger the family size is also put positive response in the consumption of different food items. This shows that if the size of the household rises the expenditure made by the consumer on different food items also rises.

Eskisehir is known as university town in Turkey, it is because some of the well-known education institutional exists in here. So it means that one of the most important province of Turkey which is preparing the young generation both for Turkey and for the students from different countries. So it is one of the main polishers of human capital. Therefore, it needs special attention to promote balance diet. The weather of Eskisehir is also a very pleasant and helpful for different crops like potatoes, maize, and different vegetables. So by making focus on the agriculture the living standard of the area can be improved. The local as well as provincial government has also to play its important role to increase the living standard in the study area. When we compare the average monthly income of the area with that of other cities of Turkey, it is good that average income in the study area is higher than that of other areas, but can be increased more and more. The study misses some of the important facts like the consumption food items from outside the home, the consumption of fast food items; a very small sample size has been taken to represent the large population. So a similar study can be conducted in the study area by adding these important facts and variable as part of the study. But the overall study gives us satisfactory result to meet our hypothesis and purpose of the study.

\section{Acknowledgements}

"A man who is unable to live in society and thinks he is self-sufficient for himself either beast or God", Aristotle. The above quota best describes the nature of a man. Being human it was not possible for me as well as completes this study without the help and support of my well-wisher and Professors i.e. Dr. Mustafa Kemal Beşer and Dr. Hakan Acaroğlu.

\section{References}

Bioline International. Retrieved from http://www.bioline.org.br/request?ja05067

Bozoglu, M., Abdulbaki, B., Yen, S. T., \& Huang, C. L. (2013). Household Food Expenditure at home and away from Home in Turkey. Agriculture and applied Economics association 2013. 
Chern, W. S., Ishibashi, K., Tangouchi, F. K., \& Tokoyama, T. (2002). Agricultural and Development Economics Division the Food and Agriculture Organization of the United Nations, April-2002.

Encyclopedia of the Nations. from http://www.nationsencyclopedia.com/economies/Asia-and-the-Pacific/Turkey.html

Garcia, A., \& Albisu, L. M. (2001). Food Consumption in the European Union: Main Determinant and Country Differences. Agribusiness, 17(4), 469-488.

Grimard, F. (1996). Does the Poor's Consumption of Calories Response to Changes in Income? Evidence from Pakistan. Pakistan Development Review. Islamabad, 35(3), 257-283. Government of Pakistan, Report of National Commission on Agriculture. March 1998. Islamabad.

Gumus, S. G., Olgun, F, A., \& Adanacioglu, H. (2010). Food Consumption Patterns in Rural Turkey and Poverty. African Journal of Agricultural Research, 5(1), 16-27, 4th January 2014.

Hymans, S. H., \& Shapiro, T. H. (1976). The Allocation of Household Income to Food Consumption. Journal of Econometrics, 4, 167-188. North Holland Publishing Company.

Kennedy, G. Ballard, \& Claude Dop, M. (2011). Guideline for Measuring Household and individual dietary Diversity. European Union. Retrieved from www.fao.org/3/a-i1983e.pdf

Meenakshi. Ranjan, J. V. R., \& Ray, R. (1997). Regional Differences in India's Food Expenditure Pattern: A Complete Demand System Approach. Department of Economics, Delhi School of Economics, Delhi University, Delhi, India. Journal of International Development, 11(1), 47-74.

Murad, A. (1998). Fresh fruits Consumption in Urban and Rural Areas: A Comparison. M.Sc (Hons) thesis. Department of Agricultural Economics, NWFP Agriculture University Peshawar.

Ofuya, Z. M., \& Akhidue, V. (2005). The Role of Pulses in Human Nutrition: A Review. Journal of Applied Sciences \& Environmental Management, 9(3), 99-104.

Popkin, B, M. (2001). Nutrition in transition: the changing global nutrition challenge. Asia Pacific Journal of Clinical Nutrition, 10(Suppl. 1), S13-S18.

Praduman, K., \& Mathur,V. C. (1996). Structural changes in the demand for food in India. Division of Agricultural Economics, Indian Agricultural Research Institute New Delhi India. Indian Journal of Agricultural Economics, 21(4), 664-673.

Regmi, A., Deepak, M. S., James, L., Seale, J. R., \& Bernstein, J. Cross Country Analysis of Food Consumption Patterns. Changing Structure of Global Food Consumption and Trade/WRS-01-1, Economic Research Service/USDA. Retrieved from http://www.ers.usda.gov/media/293593/wrs011d_1_.pdf

Salama, O. M. (1995). Consumption Functions and Expenditure Pattern of food in Egypt. Faculty of Agriculture, Moshtohor Zagazig University, Egypt. Annual Journal of Agricultural Science Moshtohor, 33(2), 429-440.

Seale, J. R., Regmi, A., \& Brenstein, J. (2003). International Evidence on Food Consumption Patterns. Electronic Report from the Economic Research Service. Retrieved from https://ideas.repec.org/p/ags/uerstb/33580.html

Turkish Statistical Institute (TurkStat), Annual Report (2012, 2013, 2014).

World Health Organization 2014 annual Report.

\section{Notes}

Note 1. Bioline International. Available online at : http://www.bioline.org.br/request?ja05067

Note 2. Encyclopedia of the Nations. Available online at: http://www.nationsencyclopedia.com/economies/Asia-and-the-Pacific/Turkey-AGRICULTURE.html

Note 3. World Health Organization 2014 annual Report 